University of Nebraska - Lincoln

DigitalCommons@University of Nebraska - Lincoln

Faculty Publications in Educational

Administration

2020

Revisiting the governance narrative: The dynamics of developing

national educational assessment policy in South Korea

Taeyeon Kim

Follow this and additional works at: https://digitalcommons.unl.edu/cehsedadfacpub

Part of the Educational Administration and Supervision Commons

This Article is brought to you for free and open access by the Educational Administration, Department of at DigitalCommons@University of Nebraska - Lincoln. It has been accepted for inclusion in Faculty Publications in Educational Administration by an authorized administrator of DigitalCommons@University of Nebraska - Lincoln. 


\title{
Revisiting the governance narrative: The dynamics of developing national educational assessment policy in South Korea
}

\author{
Taeyeon Kim \\ Michigan State University \\ Correspondence — Taeyeon Kim, email tkim@unl.edu \\ ORCID Taeyeon Kim https://orcid.org/0000-0002-2020-9851
}

\begin{abstract}
This paper argues that the 'new governance' narrative should be revised and modified to reflect context-specific details of the policy sector and styles of government. I discuss the modified network governance narrative, including how the theory of bureaucracy informs the function of network governance. I then apply it to analyze a case study of Korean educational assessment policy, specifically the National Assessment of Educational Achievement, as empirical evidence to support the claim. The case study revealed that central government was a major force in the policy development, and its bureaucratic power combined with soft and hard capital was strong. Responding to central government, opposing groups tried to change the policy by forming networks for collective action, utilizing the media and discovering flexibility within bureaucratic rules, which led to partial changes of the policy in the next regime. The study concludes with several remarks that contribute to policy analysis in education: (a) the usefulness of the modified network governance framework in analyzing policy; (b) bureaucratic structures as useful resources for stakeholders in policy; (c) educational and political beliefs as critical factors in forming and tightening networks; and (d) broader implications for understanding testing policy in Asian contexts.
\end{abstract}

Keywords: Educational governance, bureaucracy, network governance, South Korea, policy analysis

Published in Policy Futures in Education 18:5 (2020), pp 574-596.

DOI: $10.1177 / 1478210319873767$

Copyright (C) 2019 Taeyeon Kim. Published by SAGE Publications. Used by permission. 


\section{Introduction}

Research on international education policies has highlighted new forms of governance characterized by polycentric decision-making, networkbased relationships, and flexibility of policy processes (Ball and Junemann, 2012; Rhodes, 1997, 2007). Governance in general implies a process of governing through the coordination of interactions between diverse actors (see Pierre, 2000; Rhodes, 2007). Peters (2000) uses the terms old governance and new governance to distinguish different focuses on governance discourses. The old governance perspective focuses on the influence of central government on society, while the new governance perspective focuses on interactions between central government and diverse policy actors in making agreeable decisions (Peters, 2000). Such a shift has been populated in governance narratives in policy literature by suggestions that using new governance framework is critical to understand policy development (Ball and Junemann 2012; Peters, 2000; Rhodes, 1997, 2007).

However, Grix and Phillpots (2011: 4) argued that this 'new orthodoxy' should be revisited and re-examined, reflecting on sector specification and regional contexts. According to Grix and Phillpots, the idealtypical governance narrative shaped in the context of British politics (i.e. big government or hierarchical state has been replaced by a new mode of governance based on networks and partnerships) deviates in the sport policy sector in the United Kingdom (UK); they suggest that 'the move to network governance in some cases is part of a state strategy to enhance control over policy' (2011: 5). This suggests the importance of understanding the new governance narratives as context-specific with multiple forms (e.g. a nation's governance structures in the specific sector).

Following their critique on the 'new orthodoxy' of governance, this study argues that the emergence of the new governance does not imply a complete shift from old governance of government-dominated bureaucracy; rather, new governance should be understood as a mixed form 'developing out of' the old governance (Rizvi and Lingard, 2010: 122). Especially in the education sector of strong states where its government authority drives the creation and implementation of national policies (Lim and Apple, 2016), I argue that the 'new governance' narratives need to be revisited and informed by the perspective of governmentdominated bureaucracy in addition to reflecting polycentric networks 
in analyzing education policies. In this paper, I discuss the modified network governance narrative, including how the theory of bureaucracy informs the function of network governance. I then apply it to analyze a case study of Korean educational assessment policy, specifically the National Assessment of Educational Achievement (NAEA), as empirical evidence to support the claim.

Recent research has highlighted the theoretical transition from old governance to new governance (e.g. Rizvi and Lingard, 2010) and the observed phenomenon of network governance in education policy process (e.g. Ball, 2012). However, international evidence of education policy in 'strong states' (Lim and Apple, 2016: 11)—where central governments exert strong power as a major policy actor in developing policies-suggests that the old governance perspective is still important in analyzing education policies (Lim, 2016; Lim and Apple, 2016; Sung, 2011). Given this context, overlooking the old governance perspective when analyzing education policy hinders the ability to capture a complete image of the strategies that multiple stakeholders from various fields use to generate policies. Thus, this study contributes to complicating the new governance narrative by discussing its context-specific nuances using an empirical example. Theoretically, this study revisits the theory of bureaucracy and explores its implications for network governance. Empirically, the findings of this study show concrete evidence of how the network governance narrative can take multiple forms influenced by specific policy contexts.

I first provide background literature to situate nation states under the influence of global education environments which have effectively shaped new governance. I then discuss modified network governance as a framework by examining the network governance narrative informed by theories of bureaucracy. Applying this lens, I analyze one of the Korean education accountability policies as a case study. I believe that analyzing the recent national test policy in South Korea reveals complicated network governance structures united with bureaucratic controls in developing policy. Korean education systems have been historically centralized, but during the past two decades the Ministry of Education and Korean governments have tried to relegate authority to local governments and schools by lauding ideas of autonomy and decentralization (Y Kim, 2016; N Park, 2013; Sung, 2011). However, the way the Ministry of Education under the Lee administration (2008-2012) developed and 
implemented the national testing policy for school education was often criticized for (a) the central government's top-down arbitrary decisionmaking approaches and (b) its conflicts with the main reform agenda such as increasing autonomy and diversity in schooling. This national testing policy process resulted in strong tensions between multiple policy actors regarding the policy. Thus, using the modified network governance framework to analyze this case is helpful in revealing the dynamics of policy actors and their strategies in policy development.

\section{Background literature}

Literature on international education has highlighted the roles of nation-state governments in forming and implementing policies from the perspective of new governance. In the debates about global and local influences, some researchers have implied that nation states exert limited powers in controlling local policies under the pressure of globalization, as compared to past centralized government leadership (Ball, 2012; Jessop, 2002; Lingard et al., 2015; Shahjahan, 2012; Rizvi and Lingard, 2010; Robertson, 2012). According to this line of research, the growth of international organizations (e.g. World Bank; Organisation for Economic Co-operation and Development (COED); United Nations Educational, Scientific, and Cultural Organization) has shaped a new method of international control (Ball, 2012; Rizvi and Lingard, 2010; Robertson, 2012; Shahjahan, 2012). International tests such as the Programme for International Student Assessment (PISA) and global educational indicators developed by these organizations have framed test-based accountability as a dominant approach to improve educational quality cross-nationally (Meyer, 2014; Rizvi and Lingard, 2010; Tuck, 2013). These global discourses around test-based accountability were often combined with neoliberal education reforms where the market is framed as a superior mechanism to have students achieve desired outcomes in the global economy (Gaches, 2018; Peters, 2012); therefore, the state government is expected to enable the market arrangements in transforming the education sector toward more decentralized and demand-oriented services (e.g. Lubienski, 2018; Verger et al., 2013). These findings have suggested that increasing market freedom in developing education policies in local governments and involving diversified policy actors-through 
private-public partnerships or advocacy networks-in policy process can weaken the centralized power of nation states in the function of network governance.

Another line of research has focused on how individual nation states manage the tensions of applying global influences to local education policies (e.g. Convertino et al., 2017; Hartong and Nikolai, 2017; Narodowski et al., 2016; Rönnberg, 2017; Steiner-Khamsi, 2012). These studies imply that, under the complexity of the new governance, different capacities of states' power and levels of marketization in the education system result in different types of governing and coordination of educational stakeholders. That is, polycentric policy networks under global influences do not necessarily weaken the centralized power of nation states in certain contexts; thus, understanding governance narratives should be informed by specific contexts of the nation state. For some countries (states) in which markets are closely connected to education systems (e.g. Alberta in Canada, England, India, Sweden), network governance functions actively and effectively in developing education policies (Ball, 2012; Lubienski, 2018; Rönnberg, 2017). For example, in Sweden, where administration, politics, and business are closely connected, Rönnberg (2017) observed that strong politicalbusiness coalitions play a critical role in the marketization of education, because its system enables policy actors to move easily between roles across these fields. In contrast, for other countries (states) in which markets are relatively limited in education systems (e.g. China, France, Quebec in Canada, Singapore), the government can utilize foreign (global) discourses as tools for increasing nation states' control over national policies. Maroy et al. (2017) analyzed two cases of the accountability policies in the province of Quebec and in France, and found that the process of localizing global ideas and reform discourses strengthened centralized government powers.

Research on education policies in Asia (e.g. Hong Kong, Japan, Singapore, South Korea) has suggested that central governments still exert strong power in developing national education policies ${ }^{1}$ (L Lim, 2016; L Lim and Apple, 2016; Sung, 2011). Accounting for historical and cultural backgrounds, nation states in Asia have actively planned and intervened in education policies, which has been instrumental in promoting the productivity of the national system (Gopinathan, 2007; IF Lee, 2018; L Lim, 2016). While market expansions in global environments 
have been influential to encourage nation state governments to diminish bureaucratic administrative controls (Rizvi and Lingard, 2010) and to borrow foreign policy discourses from more dominant global players (Sung, 2011; Takayama, 2008), strong states including Korea have tended to maintain centralized power in order to control education policies (e.g. Han and Ye, 2017; L Lim, 2016; Sung, 2011). For example, with the uniqueness of the Chinese political system and Confucian precedent, education policymaking in China does not follow the existing discourse of network governance in the West. Han and Ye (2017) showed that bureaucracies and state endorsements exerted a strong influence on education policy making in China. These findings indicate that governments in strong states can still increase the state's controls by utilizing bureaucratic structures and global discourses in driving education policies.

\section{Theoretical framework}

In describing changes of governance discourses, Peters (2000) used the terms old governance and new governance. ${ }^{2}$ In old governance, governments play a leading role in driving policies, while in new governance, interactions and networks between governments and other stakeholders are significant in forming policy decisions (Peters, 2000). Although the new governance perspective is gaining influence in relation to governance in today's education policies, both governance forms exist in developing education policies in any nation-state context unless governments refrain from participating or solely driving policy. While I acknowledge critical roles of networks and partnerships in developing education policies in general, I argue that state government as a key policy actor can still maintain its control over policy process relying on bureaucratic structures depending on context. For example, in the context of strong states like Korea, the degree to which bureaucracy is involved in developing education policy may be higher than in other countries in the function of network governance. Thus, this section outlines network governance, framed as an orthodox narrative, and bureaucracy, framed as a revisited narrative, to better understand the modified perspective of new governance. 


\section{New governance narrative: network as ideal typical governance}

In developing the 'new governance' narrative, the concept of policy networks has been popularly used to analyze education policy-making processes (e.g. Ball and Junemann, 2012). According to Ball (2012), the rise of network governance is closely linked to the rise of neoliberalism. Harvey (2005: 2) suggests that neoliberalism seeks 'liberating individual entrepreneurial freedoms and skills within an institutional framework characterized by strong private property rights, free markets, and free trade'. Thus, neoliberalism creates new spaces for the emergence of diverse stakeholders and transnational policy actors, which shifts governance in education policies (Ball, 2012; Robertson, 2012). Neoliberalism makes our everyday lives and social relations market-oriented in pursuit of capital accumulation and profit-making (Wood, 1997). This view of neoliberalism involves material and social relations (Ball, 2012), and also includes 'reconfiguring relationships between governing and the governed, power and knowledge, and sovereignty and territoriality' (Ong, 2007: 4). Boundaries between policy actors and spaces become blurred, as relationships between actors are complex, opaque, interwoven, and hybrid (Ball, 2012). As traditional, fixed authority no longer informs, creates, and implements policies, different types of capital (such as culture, money, and knowledge) are invested by different actors in complex networks. At the end, the influences of neoliberalism percolate in our political and social environments, civil society, daily life, and subconscious.

Given this concept, new governance reflects influences of neoliberalism. Ball (2012) suggests three features of today's policy environments:

1. Private-public partnerships, transnational advocacy networks and policy entrepreneurs are commonly observable.

2. Based on the fluidity of market mechanisms, resources and influences in network governance are bidirectional rather than unidirectional.

3. A state in a new governance reconstructs its roles from service delivery to a combination of monitoring and controlling new public service providers.

Network governance exhibits more complex dynamics in relationships between actors and power formation in education policy 
environments. In this new governance, capital plays a critical role in making and transferring policies. This capital includes soft capital, such as relationships in networks and governing knowledge, as well as hard capital, such as money. To create and expand the education market in the public sector, controlling knowledge is critical in the diffusion of new policy narratives via questioning older ones (Ball, 2012; Grek and Ozga, 2010). Diverse stakeholders, including commercial consultants and public service companies, utilize strategies to expand their powers by suggesting market- based solutions and changing the relations between organizations, such as the development of partnerships and contraction in the public arena (Ball, 2012). As such, new governance sets the neoliberal norms that represent education as a business and educational policy as a commodity to be bought and sold.

\section{Revisited narrative: bureaucracy in governance}

Policy can be understood as one of the governing mechanisms for the state (Shore and Wright, 2000). In this case, while network governance plays a critical role in policy development, it is hard to overlook the role of bureaucracy in policy analysis because all the education systems in which policy interventions occur include certain levels of bureaucratic controls. Weber (1968) argued that bureaucracies are inevitable organizational forms in modern societies because all societies are organized by hierarchical authority dimensions, predicated on power. These functions of bureaucracy are observable in many education systems and utilized in forming governance.

Weber's (1958) theory of bureaucracy posits that legal rational authority and bureaucracy are popular means of domination in modern societies. A legal code covering everyone in a territory should exist, and therefore people can predict the penalties for infringements, including the rulers themselves (Allen, 2004). This legal code system allows bureaucracy to highly develop the description of roles and responsibilities for administrative staff. Each has a determined zone of competence sets around their job descriptions (Weber, 1958). These areas of jurisdiction give them the power to fulfill their obligations in these predefined ranges. Staff's actions, jurisdiction, and obligations are governed by rules that exist in written form. Thus, people who are subject to authority obey their superordinate because they accept the impersonal norms 
defining that authority, not because they accept any personal dependency. Given this system, the essential principal of bureaucracy is 'domination through knowledge' (Weber, 1968: 225). Bureaucracy creates spaces for filing knowledge to ensure that those at the top have special knowledge of facts and exclusive access to stored documents and information (Weber, 1968). Bureaucratic systems control knowledge and actions by excluding the public to avoid criticism.

For Weber, bureaucracy is the most technically efficient form of organization, as it favors 'precision, speed, unambiguity, knowledge of the files, continuity, discretion, unity, strict subordination, reduction of friction and of material and personal costs' (Weber, 1968: 973). Weber assumed that, once established, bureaucracy is a permanent machine and can work for anyone in control of it. Although Weber assumed bureaucratization is the most efficient form of organization, and therefore inevitable, he worried about increasing depersonalization in its mechanisms. Thus, he suggested that the top of a bureaucratic system needs to have an element that is not entirely bureaucratic, such as having a charismatic leader in the system (Weber, 1968). While Weber developed theories of bureaucracy in the emergence of modern societies, it is still valuable in explaining the governance of contemporary education policies. Bureaucracies exists at different levels of our social structures, a phenomenon that is closely connected to how governments create power and dominate actors in driving education policies. Table 1 shows a comparison between bureaucracy and network governance.

\section{Modifying the 'new governance' narrative}

In this paper, I argue that the new governance narrative can be informed by theories of bureaucracy in understanding policy process for several reasons. First, policy-making involves legislation process, and policy implementation often relies on administrative organizations; therefore, policy development in general cannot avoid the function of bureaucracy. While networks and partnerships in the policy process allow flexibility and fluidity, written rules and legal codes can regulate who makes the final decisions in certain sectors. In some contexts, central government can be dominant in deciding how to implement the policy process (Weber, 1958). 
Table 1. Bureaucracy and network governance.

\begin{tabular}{|c|c|c|}
\hline & Bureaucracy & Network governance \\
\hline Context & $\begin{array}{l}\text { - Fixed form of organization } \\
\text { - Rigorous membership } \\
\text { - Reduce complexity to protect } \\
\text { organizations } \\
\text { - Pursue organizational effi- } \\
\text { ciency to achieve organiza- } \\
\text { tional goals }\end{array}$ & $\begin{array}{l}\text { - Complex dynamics in relationships be- } \\
\text { tween actors } \\
\text { - Flexible membership } \\
\text { - Try to maximize actors' interests }\end{array}$ \\
\hline Actors & $\begin{array}{l}\text { - Governments play a dominant } \\
\text { role in making and imple- } \\
\text { menting policies }\end{array}$ & $\begin{array}{l}\text { - Governments make decisions influ- } \\
\text { enced by other agents, such as inter- } \\
\text { national organizations, private organi- } \\
\text { zations, individual actors, etc. }\end{array}$ \\
\hline Main strategies & $\begin{array}{l}\text { - Legal authority-setting laws } \\
\text { and written form of rules } \\
\text { - Organize hierarchy (boundar- } \\
\text { ies of authority and function) } \\
\text { - Regulate external power } \\
\text { - Control knowledge } \\
\text { - Top-down approach to educa- } \\
\text { tion policies }\end{array}$ & $\begin{array}{l}\text { - Soft capital: create discourses and } \\
\text { agendas to problematize; utilize mass } \\
\text { media to diffuse formed problems and } \\
\text { new solutions } \\
\text { - Hard capital: financial and physical } \\
\text { investment } \\
\text { - Exchange resources } \\
\text { - Make alliances }\end{array}$ \\
\hline
\end{tabular}

Second, in forming networks, bureaucratic structures can be utilized as resources by some policy actors; their capacities to attain and utilize resources are not symmetrical (e.g. Grix and Phillpots, 2011). The network governance perspective assumes that policy actors create and change formal and informal rules by actively framing problems and inventing new solutions to increase their own interests through policy processes (Ball, 2012; Ball and Junemann, 2012). In this process, if a certain sector of the state rests upon bureaucratic structures, hierarchy sets territories of authority depending on positions and areas, and central government can influence all the staff in the system. At the same time, rules also define and limit the jurisdiction of central government, in which case bureaucracy serves as a resource to protect the rights of members within the system and allows room for other policy actors to be involved. Thus, how policy actors utilize bureaucracy is critical in deciding their influences on policy decision-making in network governance. Third, strategies found in network governance and bureaucracy work together in the development of policy. Network governance seeks efficiency and effectiveness based on individual or group interests rather 
than fixed authority (Ball, 2012). Exchange-as opposed to authority-is the main mechanism determining the relationships between diverse organizations and individual actors. A combination of soft capital-knowledge creation and diffusion via mass media including social media-and hard capital-such as money_plays a critical role in shaping power and determining power directions. These strategies are utilized for setting or changing laws in pursuit of group interests. Responding to multiple actors, the government can regulate the involvement of external agencies (e.g. foreign agencies or private companies) who want to intervene in local education systems. Bureaucracy may also allow governments to produce internally legitimate knowledge with selective groups of people (e.g. professionals, government elites) excluding the public (Allen, 2004; Weber, 1968). Once a policy is approved, the government often uses top-down chains of authority to deliver policy agenda and implement the policy.

Thus, policy development incorporates elements found in both old and new governance narratives. Especially in the context of strong states, using the lens of network governance informed by the theories of in bureaucracy is helpful to understand how central government as a strong policy actor drives the process of policy development. In the following section, I describe the contexts of education policy development in Korea to set the stage for the case analysis used in this article.

\section{Education policy development in South Korea}

\section{Education reform trends in Korea}

The Korean government has been a key player in creating and implementing education policies (Y Kim, 2016; CJ Lee and Kim, 2016; Sung, 2011). The May 31 Education Reform of 1995, a notable turning point in educational reform in Korea (CJ Lee and Kim, 2016), provided the foundations for reform movements that persist into the present, by introducing a number of policies relying on neoliberal reform ideas (Y Kim, 2016; N Park, 2013). The May 31 Education Reform aimed to increase autonomy for local education offices and individual schools, devolve authority from the Ministry of Education to local offices, and provide consumer-centered education service (Committee on Education 
Innovation, 2006; SY Kim, 2008; N Park, 2013). While the regime has changed five times since then, every new government has proclaimed its educational policies developed in accordance with the May 31 Education Reform proposals, regardless of its political orientations (Y Kim, 2016; CJ Lee and Kim, 2016).

After this reform, the government decentralized its authority step by step. The following reform efforts at the national level have focused on a shift from traditional ways of test-based education to all-round education in schooling. For example, university entrance policies have increased the emphasis on students' in-house school data and factors other than the College Scholastic Aptitude Test (CSAT). In 2019, about $30 \%$ of incoming students to universities were recruited based on the application process which utilizes CSAT results as a critical factor. However, the other $70 \%$ of incoming students were selected based on the process which relied mainly on students' school-level data and individual portfolios without reflecting CSAT results or using them as a minimum standard after the decision was made. These policy efforts intended to lower the 'education fever'-parents invested a lot in private institutions or tutoring for their children's education to help them be more competitive in their school outcomes-and make school education focus more on students' holistic development and be less competitive. Especially at the elementary school level, standardized testing has been removed and learner-centered education has been reinforced by multiple reforms. Thus, there has been an agreement in Korean society that elementary school education is for well-rounded education and not necessarily for increasing academic skills.

\section{Education policies under the Lee Myung-bak administration (2008-2012)}

The Lee Myung-bak administration (2008-2012) accelerated school reforms promoting school diversification, autonomy, and accountability. For example, with a policy promoting school autonomy, the Ministry of Education immediately abolished several regulations that were considered to hinder individual schools' curriculum or budget decisions (SU Lim, 2011). The school diversification policy extended private and public autonomous high schools where individual schools have more autonomy in operating schools than regular schools do (SU Lim, 2011; Suh, 
2009). The government also announced that it would devolve authority from the Ministry of Education to municipal or provincial levels to promote the local self-governing system in education (Suh, 2009). The Lee administration argued that autonomy should be granted only if schools achieve accountability to meet consumers' needs and maintain the quality of public education (Suh, 2009).

While educational stakeholders took the view that increasing schoollevel autonomy is needed in the Korean school context, they were also worried that specific policies might increase gaps between schools (SU Lim, 2011; Suh, 2009). The most often mentioned concern was that central government's decision-making in the development of policies was arbitrary and closed, ignoring concerns and side effects expressed by education experts and policy actors at the local level. ${ }^{3}$ Researchers criticized central government by saying that it was lacking democratic communications with multiple agents in education, while online platforms and social media led multiple actors to engage in conversations around education policies, unlike the past (CJ Lee and Kim, 2016; SU Lim, 2011; Suh, 2009). Sung, a professor in education, argued that 'the Ministry of Education defined autonomy for schools and teachers in their own view without knowing how schools and teachers actually consider autonomy. ... The Ministry of Education caused so many conflicts with superintendents by attempting to control them' (SU Lim, 2011: para 5). Such topdown approaches to policy processes seemed to hinder the Ministry of Education in achieving intended positive outcomes, by not being open to hear from local policy actors.

\section{NAEA Policy: accountability for autonomy and decentralization?}

The NAEA was intended as a tool for assessing students' level of achievements and for screening under-achieving students who need additional supports. The NAEA was considered as one of the main strategies for reinforcing test-based accountability. Unlike previous national test policies that used random sampling methods to recruit students (after 1998), the NAEA policy revived the use of traditional population surveys in Korea to assess the academic achievement of every student in one selected grade from each education level, including the elementary school level. The Ministry of Education enacted the NAEA for all student populations from 2008 to 2012. All 6th-grade elementary school students, 3rd-grade 
middle school students (9th grade), and 2nd-grade high school students (11th grade) across the nation had to take the test, and the results of the achievement test (ranked by districts and regions) were publicly released.

It was unusual and surprising in Korea to have all the students (in a specific grade) tested on the same day (even for elementary students) and to release district rankings to the public. This is because students and parents in Korea historically give high priority to test scores and university entrance exams, which has resulted in expanding the private education market and adding psychological pressures for students (S Lee and Shouse, 2011). In addition, since students are assigned to schools based on their zip codes or lottery system, given the assumption that the quality of schools and teachers (including private schools ${ }^{4}$ ) are theoretically the same, releasing district rankings to the public disrupted the notion of equality in school education and delivered an unintended deficit framing of certain communities in the region which were at the bottom level. Thus, the NAEA policy was against reform messages encouraging student-centered education previously highlighted in Korean education policies (before the NAEA). The NAEA policy even conflicted with and undermined values lauded by the Lee administration, such as diversity and autonomy.

During the NAEA policy implementation, tensions and conflicts between the Ministry of Education and other actors who opposed the policy increased. However, the Ministry of Education under the Lee administration maintained the original plan of the NAEA policy. Due to continuous resistance and criticism from the public and educators that the NAEA hinders well-rounded education in schools, the NAEA policy was changed in the following regimes. In 2013, the national assessment was abolished for 6th-grade students and test subjects for middle school students were reduced via the NAEA (Ministry of Education, 2013a, 2013b). In 2017, the Ministry of Education announced that NAEA policy would use a sampling approach eliminating the national-level population testing for students.

This study mainly focuses on the NAEA policy in the period of the Lee administration for several reasons. First, it appeared that the NAEA policy approaches using a population survey did not align with the mainstream flow in Korean education reform movement historically and culturally. Korean school education was in the middle of the process 
of removing rankings- and competition-based evaluation in assessing students, but the NAEA policy, often called 'backward policy,' increased pressures on classroom practice towards the test preparation. This policy approach seemed to be an oddity in the context of national education reform in Korea. Second, although the Lee administration explicitly addressed the importance of decentralization, autonomy, and diversity for individual schools (Y Kim, 2016; N Park, 2013), the NAEA policy implementation was coercing every school in the nation to participate regardless of the local decisions. Third, although the Ministry of Education stated that the NAEA was needed for screening students, another diagnostic test was already being implemented each year across elementary and secondary schools in Korea, and therefore schools had to implement both tests. Lastly, while there were heated debates around the NAEA in terms of using a population survey in Korean society involving multiple groups that included students who resisted the policy, the Lee administration continued to implement the original plan of the policy. Therefore, examining the NAEA policy during the Lee administration provides useful examples about how central government drove the NAEA policy and how other stakeholders responded to the government's actions.

\section{Method}

This study aimed to analyze how the NAEA policy was developed and what types of strategies policy actors used in driving the policy, by applying the modified network governance narrative. I conducted a document analysis using government documents, policy reports, and news articles about the NAEA policy. Document analysis is useful to conduct interpretative analysis about the NAEA policy development in that it helps identify underlying assumptions and ideologies that reflect policy environments and government intentions (Shaw et al., 2004). The final data sources were 137 documents in total including government documents, policy reports, legal reports and news articles. I searched data sources (published from January 2000 to June 2017) using the keywords 'NAEA policy, 'education policy of Lee administration,' and 'national test policy' in Internet search engines, including Google, Google Scholar, Research Information Sharing Service (RISS), the Ministry of Education website, and the education newspaper search service provided by the 
Korean Federation of Teachers' Associations (KFTA) website. Regarding news articles, when multiple news companies reported on the same contents of articles, I focused on articles published in Yeonhapnews, the only news agency in Korea.

I first categorized the documents by time and identified major themes. These themes were highlighted based on the elements found in bureaucracy and network governance perspectives. I found that the NAEA policy development can be divided into three stages with reference to remarkable shifts that occurred during policy development: (a) policy formulation, including agenda setting and pre-investigations; (b) policy implementation, the period when the policy was activated and implemented; and (c) changing the policy after the first five years of implementation. Each stage is described with consideration for policy actors and their strategies to regulate the NAEA policy. Second, for each stage, I analyzed texts to understand how the NAEA policy was developed using the categories of major actors, contexts, and strategies used by the actors, drawing on the analytical lens of the study as shown in Table 1. I analyzed the collected documents, focusing on (a) dominant policy actors and the relations between actors; (b) specific events and contexts highlighted in documents:, and (c) structures and functions of bureaucracy combined with the strategies described in network governance.

\section{Findings}

\section{Formulating the NAEA policy}

To justify the rationale of NAEA policy, the Korean government made efforts to establish a legal foundation and utilized accountability discourses from international test policies (Ministry of Education, 2008). At this stage, the main actors were the Ministry of Education and the National Assembly, particularly Joo-ho Lee, ${ }^{5}$ who was largely responsible for creating the policy (N Park, 2013).

Before the NAEA policy was officially announced, several associations on the progressive side announced their opposition to the policy by making alliances, protesting, and using the media to actively earn support from the public (N Park, 2013). These associations consisted of the Korean Teachers \& Educational Workers' Union (KTU), the National 
Association of Parents for Cham-Education, and the Lawyers for a Democratic Society. These collective movements agreed on the need for accountability in education, but argued that the government needed to find a better way to pursue authentic educational goals, rather than focusing on test scores. These associations questioned the role of the NAEA in achieving accountability. That is, the original purpose of accountability is to support well-rounded education through teachers' expertise and devotion to education, but the NAEA hindered the achievement of this purpose. As conflicts arose between both sides, justifying the NAEA policy was important for the Ministry of Education. In this context, notable strategies were establishing legal foundations and controlling knowledge used by the government.

Establishing legal foundations. According to the NAEA report, there were two legal foundations upon which the enactment of the policy was built (Ministry of Education, 2008). Jooho Lee, a proportional representative member of the National Assembly in 2004, proposed The Enactment of Exemption Law about A Public Information Act of Education Institution. The purpose of this law was to guarantee public access to educational information and increase efficiency and transparency in public administration. When the exemption law was passed, an enforcement ordinance about A Public Information Act of Educational Institution (17 November 2008), designed to provide foundations to open the results of the NAEA assessments to the public, was released (N Park, 2013).

As legal authority is a fixed form and hard to change, the establishment of legal foundations efficiently supported central government's initiation and regulation of the NAEA policy despite strong resistance from other actors. Recognizing this, Lawyers for a Democratic Society, who were against the policy's initiation, tried to change the enforcement ordinance regarding this law through court decisions. The Lawyers for a Democratic Society (2007) presented a written opinion stating that they agreed with the purpose of the Exemption Law about A Public Information Act of Education Institution, but, considering social ramifications, the enforcement ordinance should be revised toward covering achievement gaps between schools.

Controlling knowledge. The Ministry of Education internally generated and dispensed brochures and videos for parents to advertise the NAEA 
policy. Throughout this process, the Korean government effectively utilized global discourses about international achievement assessments. As international assessment results became popular, the Korean government and the public became more interested in assessment-based accountability systems (N Park, 2013). According to Shin-bok Kim, the former Vice Minister of Education, Korean education policies have been created to sensitively respond to the Programme for International Student Assessment (PISA) results after 2000 (Shin and Joo, 2013). Supporting his claim, government-funded research reports suggested that the NAEA assessment contents were modeled on PISA, Trends in International Mathematics and Science Study (TIMSS), and the National Assessment of Educational Progress (KICE, 2012). The rationale of the US No Child Left Behind (NCLB) Act was used for the Ministry of Education to legitimize the NAEA policy (Sung and Kim-Koh, 2009).

In setting agendas, the Ministry of Education strategically delivered selective knowledge to the public to create a rationale of the policy. Since international assessments used sample surveys and not population surveys, the government did not explicitly mention details about their methods, and instead selectively advertised the effectiveness of the international tests for accountability. They did not specifically mention why the population-based test was needed (accuracy of reporting), which was key to the policy agenda. As the authority flowed top-down in terms of assessing needs to develop the NAEA, the Ministry of Education directed research institutes to analyze the needs of national-level assessment policy and opened their final decisions to the public right before enactment of the policy (see Nam et al., 2014).

\section{Implementing the NAEA policy: increased conflicts between actors}

The Ministry of Education released the results of the NAEA in 2009, and tensions and conflicts increased between the Ministry of Education and policy actors who opposed the NAEA implementation. After the Ministry of Education officially announced the enactment of the NAEA in 2008, five associations from the progressive side-including KTU, parent organizations, and civic groups-actively resisted (N Park, 2013). These organizations announced civil actions to reject the NAEA and planned field trips on the test day with parents who advocated the rejection. They also applied for an injunction and a petition to remove the NAEA policy. 
Moreover, it is notable that students participated in protests opposing the policy, and the superintendents who supported the progressive party resorted to strong counteractions in response. Criticizing these protests, four associations from the conservative side-including the KFTA, parent organizations, school board groups and civic groups-suggested that finding better ways to utilize the test results was important and that it was detrimental to reject the NAEA policy through the media (Yeonhapnews, 2008).

At this stage, conflicts increased between the Ministry of Education and superintendents who supported the progressive party, which led to a high number of lawsuits in education. Regardless of criticism and resistance, the Ministry of Education consistently implemented the NAEA policy and utilized the test results to support the autonomous school policy and excellence-education policy. For example, the Ministry of Education included indicators that reflect test results to evaluate schools, local districts and Offices of Educations at the municipal/provincial level. At this stage, actors used more complicated strategies to drive policy direction. The main strategies were creating new discourses and maximizing bureaucratic resources with alliances of political support.

\section{Creating new discourses: alliance with professional authority and media}

To support the policy implementation, the Ministry of Education highlighted the usefulness of the NAEA results by using its professional authority. As outcomes of the NAEA accumulated, government-funded research institutions, such as the Korea Institute of Curriculum and Evaluation (KICE) and the Korea Educational Development Institute (KEDI), conducted research on how to use the data to suggest directions for future education policies (see Y Kim et al., 2009). The Ministry of Education collaborated with KICE annually and invited individual researchers and research institutions to join in the contest to conduct more research using NAEA data. Some professors in education valued the rich information represented in NAEA data, while simultaneously warning that the data should not be used for punishing teachers and schools based on test results (Jung, 2015; SY Kim, 2008). The country background report conducted for OECD data (Kim et al., 2010) also supported the NAEA policy implementation by mentioning that Korean students' high-achieving 
scores from PISA 2000 to 2009 were due to the utilization of test policies in Korea and valued the effectiveness of the NAEA in monitoring the accountability of public education and student achievement.

In creating discourses, the media was a critical component in spreading problems and solutions framed by the policy actors. After the Ministry of Education released the test results to the public, most news outlets reported the assessment results by mainly focusing on district rankings, especially regarding which regions and which types of schools were at the top and bottom levels (Y Lee, 2009). As Korea has a large private educational market, private education companies advertised strategies to increase test scores and marketed their new materials after the Ministry of Education announced the NAEA implementation. Their advertisements and marketing framed discourses about the importance of competition, risk of public education, and efficiency of private institutions (mainly hagwon in Korea). According to statistics, private education expenses per person increased steeply between 2008 and 2009 and stayed higher than previous years (Statistics Korea, 2017).

The media also played an important role in furthering protests by reporting how publicizing the test results influenced local schools. For example, the media reported that schools provided longer hours for test preparation, even in elementary schools, and decreased instruction hours for subjects that are not included in the NAEA test, under the pressure of provincial and regional offices of education (see Cho, 2008). In addition, as students participated in counteractions, progressive media shaped these situations to justify efforts against the NAEA, while conservative media outlets criticized opposition groups by framing their actions as anti-educational (N Park, 2013).

Maximize bureaucratic resources: flexibility vs control. In implementing the NAEA policy, both the Ministry of Education and superintendents who opposed the policy tried to maximize their territories of control within the bureaucratic system. As the direct election of superintendents started in 2007, Korean superintendents were freed from the topdown approach of central government compared to the previous system. In order to support opposition movements, some provinces whose superintendents were supported by the progressive party tried to utilize the flexibility given under the NAEA policy. For example, relying on the authority of their superintendents, some offices of education changed 
plans in regard to other assessments that were not mandated by law. The superintendent of the Kyung-gi province allowed schools and students to make decisions as to whether or not they would take the diagnosis assessment. In 2011, the Office of Education in Seoul announced it would give autonomy to individual schools in terms of reporting the results of the diagnostic assessment. For example, schools had the option of reporting results in only pass or fail form to students and parents (Hwang, 2011). In addition, several students from a variety of regions intentionally missed school on the test day with approval of their parents and schools (Uhm and Park, 2008; Yun, 2009). Several middle schools in the North Jeolla Province boycotted the test, opting instead to hold regular classes (Cho, 2008). Throughout the implementation process, several superintendents found flexibility within the bureaucratic system and utilized this flexibility to perform counteractions to protest the policy. These increased tensions between the Ministry of Education and superintendents who did not comply with the NAEA policy were highlighted by the media and politicians.

To control protests, the Ministry of Education used its authority of evaluation and budget allocations for offices of education to change evaluation indicators based on compliance with the NAEA policy and manipulate resource allocations at the national level (Choi, 2012; Y Park, 2012). Moreover, some school administrators and school educators who participated in actions to reject the NAEA policy were punished by their offices of education based on legal authority (such as disposition of salary reduction, suspension, and dismissal). ${ }^{6}$ In this sense, actors on both sides tried to maximize their power to control the policy by utilizing the bureaucratic systems in which they were situated. Furthermore, these strategies were allied with political resources. The Ministry of Education was supported by the conservative party (holding the government) and superintendents who protested the policy were supported by the progressive party. Unlike other previous ministers of education in Korea, whose average incumbency was about one year, Joo-ho Lee, the Minister of Education in the Lee administration, continuously served in his role for two and half years, pushing the NAEA policy. Because of the involvement of political interests, the NAEA policy implementation caused a rise in conflicts. 


\section{Changing the policy}

Due to the resistance and criticism from the public and educators, achieving the government's intended purpose of guaranteeing accountability of individual teachers and schools through the NAEA results was unsuccessful (N Park, 2013). Through the continuous debates on the NAEA policy, the Korean government saw that society was divided based on conflicts between progressive and conservative groups regarding educational orientation. However, the Ministry of Education and the Lee administration consistently implemented the original plan of the NAEA until 2012. Finally, after the presidential election in 2013, the Ministry of Education under the Park administration announced that the NAEA policy would exclude elementary school students and reduce the test subjects for middle school students (Ministry of Education 2013a, 2013b). From 2013 to 2016, the NAEA policy followed this revised plan under the new Minister of Education because the new government recognized public opinion. ${ }^{7}$

Involving public attention. By spotlighting the conflicts between diverse policy actors, the media successfully enabled public criticism of the policy. Within Korean cultural and social backgrounds, which value school education and parents' involvement in their children's education, the media strategically touched on emotions that captured public attention during the NAEA policy development. Both support and opposing groups strategically utilized the media to criticize the other side.

Opposing groups allied with progressive media highlighted collective actions against the NAEA policy and effectively appealed to the public, relying on cultural and social norms of valuing whole-person education. They framed the NAEA policy as backward in that the policy fostered ranking-oriented and test-based school education, which has been frequently cited as one of the endemic problems in traditional Korean education. The media favored issues regarding harmful effects of the NAEA policy on students. Additionally, the media delivered images of students' struggles with preparing for the NAEA, such as extended school hours and practicing multiple-choice tests in classrooms. Since Korean society has agreed on the importance of well-rounded school education for the last two decades, the media coverage on a crisis in elementary school classrooms and middle school students' protests provoked the public's criticism of the policy. 
Support groups allied with conservative media and utilized indirect and subtle strategies to appeal to the public. They criticized the extreme reactions from opposing groups via media coverage. Conservative media criticized protests against the test, stating that methods such as missing school to reject the NAEA were anti-educational. In addition, they used subtle rhetorical strategies to turn the public's attention to positive outcomes of the policy. For example, conservatives did not explicitly welcome the NAEA policy, but focused on the usefulness of the test results to support relevant resources in individual schools and students.

While the media delivered arguments from both supportive and oppositional sides regarding the NAEA implementation, the side effects of the NAEA for students received more attention from the public. Although the involvement of the public did not change the NAEA policy during the Lee administration period, it affected change in other assessment policies during the Lee administration and led to the revision of the NAEA policy (excluding elementary school students and reducing test subjects at the middle school level) in the next regime.

\section{Summary of analysis: modified new governance narrative}

The results of this case study reveal that the modified network governance lens helps us understand the NAEA policy process comprehensively by capturing how bureaucracy was combined with the function of network governance. It can be seen that, although the Ministry of Education transferred a large portion of authority to provincial and local levels through other policies, it strengthened its controls over test-based accountability at the local and school levels. This means that central government had strong capacities to achieve its aims through the NAEA policy during the Lee administration period.

Many elements explained in the new governance perspective are found in the development of the NAEA policy. Actors tried to reflect their interests in political actions by utilizing the media, exchanging political power, and taking legal actions. Government-funded research institutions, the OECD, private education enterprises, and conservatives welcomed the NAEA policy by creating discourses about the benefits at the local, national and global levels. The Ministry of Education also strengthened networks in support groups using both soft (e.g. problematizing actions of opposition groups) and hard capital (e.g. national level budget distribution) providing resources. Opposition movements were 
developed by progressive associations, including some superintendents, parents associations and the teachers' union. The superintendents who protested against the policy gained political support from the progressive party. Students also represented their actions and opinions to protest against the policy, and the media spotlighted their activities.

At the same time, the function of bureaucracy was found in network governance. In the complex dynamics among actors, the central government drove the NAEA policy implementation during the Lee administration, not negotiating any partial changes that happened in the following regimes. The Ministry of Education at the top of the hierarchy had relatively more resources and easier access in establishing laws and controlling knowledge, compared to the other actors. As written rules and hierarchies are not easy to change, bureaucratic structures as resources efficiently operate in achieving organizational aims towards a top-down process, even though the Ministry of Education encountered strong opposition. Moreover, the leader from the top level-Joo-ho Lee, the Minister of Education-exerted significant power in driving the NAEA policy from the beginning and up until the next administration. This move echoes Weber's (1968) argument that a leader at the top in the bureaucracy needs to have charismatic leadership to lead the system in pursuit of its values. Strategies used by opposition groups also showed elements in the theory of bureaucracy. Some superintendents, administrators, educators and students in the education system were able to take actions to oppose the policy implementation with their own rights protected by the law, even though the Ministry of Education brought multiple law suits against these actions.

Thus, the modified new governance framework that combined the view of bureaucracy with network governance is helpful in explaining empirical examples in the context of the NAEA policy process. These findings suggest that network governance involves the function of bureaucracy, and policy actors may utilize bureaucratic structures as resources in policy process depending on contexts, especially in strong states but not necessarily limited to them.

\section{Concluding remarks}

To conclude, this paper argues that a revised narrative of network

governance that includes the theory of bureaucracy in the function of 
networks is helpful in analyzing education policies in a Korean context. Although central government has consistently attempted to decentralize the Korean education system for the past two decades, the case analysis reveals that the Ministry of Education under the Lee administration increased centralized controls over student assessment through the NAEA policy. This case analysis shows a counternarrative of the 'idea-typical conceptualization of a shift' from old to new governance (Grix and Phillpots, 2011: 15). Thus, the 'new governance' narrative should be revised and modified to reflect context-specific details of the policy sector and styles of government.

As Grix and Phillpots (2011) noted, to understand why the education policy in South Korea does not appear to fit the shift in governance narratives, it is important to acknowledge discourses focusing on testbased accountability in education. The combination of globalization and new public management has created a performance-oriented culture in education (Rizvi and Lingard, 2010), which leads to what Ball (2012) calls 'reregulation' and what Du Gay (1996) calls 'controlled decontrol' through test-based accountability discourses. These processes involve 'hybrid mixes of bureaucratic and new public management structures and relationships' (Rizvi and Lingard, 2010: 122). This study shows that central government can take advantage of utilizing accountability focused narratives as resources to strengthen bureaucratic centralization, while the government's policy agendas appear to be in favor of decentralization and autonomy.

Based on the findings, this study offers four wider implications for education policy analysis. First, analyzing the policy only with old governance or new governance perspectives can overlook complicated strategies utilized by diverse policy actors. While multiple policy actors are involved in the decision-making processes of policy development, state governments as the final decision-maker utilize their authority within bureaucratic structures and create complex strategies which combine multiple resources of power to drive the policy. Responding to these actions, other policy actors also develop strategies by utilizing resources which include alliances, collective actions, soft and hard capital, and legal codes. Therefore, both old governance and new governance perspectives are useful to understand policy development comprehensively.

Second, the NAEA case analysis reveals that bureaucratic structures are instrumental resources for policy actors. Especially for central government at the top of the hierarchal system, its legal authority and 
written rules are effective in controlling knowledge, regulating external influences and driving education policies according to the government's intentions. Moreover, if the policy actors can maximize discretionary authority for themselves within the systems, as the NAEA case implied, bureaucratic structures also provide resources for multiple policy actors. This is done so that formal and written rules do not control all the actions and also protect members' rights to express opinions and collective actions for their own interests. Therefore, the bureaucratic strategies and structures are significant factors in developing strategies even in network governance. This could more often be found in the context of strong states, but not limited to them because most policy processes in different contexts may include legislation processes and bureaucratic chains within their education systems. Bureaucratic structures continue to be effective, stable and less complex tools to exert power, as Max Weber (1968) argued.

Third, while previous literature has indicated that market interests play a critical role in forming network governance, this study suggests that educational beliefs and philosophies are also important in forming and tightening networks in policy development. Building great alliances between interest groups is needed if they want to change central government's decisions, especially when the state is strong. Within a system where market intervention is relatively limited in public education, such as in Korea, ${ }^{8}$ political and educational beliefs are fundamentally influential in creating network governance, rather than market interests. This can be attributed to the cultural traditions and social systems of the local context, which calls for further examination of patterns and evidence to prove this idea.

Fourth, regarding the education context in Korea and other East Asian countries where test scores have been highly regarded in evaluating students, resistance from multiple groups to oppose national-level testing, NAEA policy, provides broader implications. It was assumed that collecting achievement data from all student populations in the country would provide useful evidence for diagnosis and further interventions to support individual students' academic needs. This logic would be well accepted by a society where testing has not been a major tool for evaluating students, where homogenous national-level curriculum is not implemented, or the whole society is not very sensitive to education reforms. However, Korea is in the middle of the reform process, 
having been shifting from a traditionally test score-focused school education to a student-oriented school environment for the past three decades. Members from diverse social groups-including students, parents, educators, researchers and politicians-are tuned to respond to changes in education policy because there is a strong belief that education is a critical tool for individuals' successes. This context helped diverse social groups form strong networks to resist the NAEA implementation because they might have recognized that the policy could result in the old-fashioned type of schooling that they experienced before. There was a view from the conservative side that eliminating national-level population testing would limit the ability to evaluate students, but this concern was not enough to keep this policy as mandated for every student and school. This response aligned with changes that had already happened-even before the NAEA policy announcement-in university student recruitment, the school curriculum and school-level assessment, towards more holistic ways of viewing students. Thus, there was a huge gap between the intended purpose of the NAEA by the Ministry of Education and how it was interpreted by diverse actors; this gap became wider in the function of network governance. This case provides an example of how network governance combined with bureaucracy works in strong states. However, the unique context of Korean education needs to be considered carefully for interpretation, not generalizing the case for other policy sectors or governments in strong states. ${ }^{9}$

In this vein, the current study contributes to diversifying governance discourses and extending analyses of global education policy through a more integrated lens. Even though fluidity and flexibility have risen in developing educational policies, the existing bureaucratic structures within the administrative system can generate useful resources and strategies for policy actors, as well as uniting with network alliances. The conditions of globalization have transformed governance, including the structure of authority, allocation of resources, and value systems, but it is important to note that this shift always involves the local contexts (Rizvi and Lingard, 2010; Steiner-Khamsi, 2012). Thus, the findings of this study suggest that governance narratives in education policy should be informed by the dynamics between local and global issues and sociopolitical environments that influence education policy (see Tesar, 2019).

Nevertheless, this study is limited in that the analysis is mainly focused on the specific Korean policy context by using document data. 
Thus, to increase usefulness of the modified network governance framework, future research can theoretically develop the governance perspective in more depth and conduct empirical analysis from diverse education policy settings. Moreover, there are some issues regarding the Korean policy case which were not covered in the scope of this paper. For example, students' participation in boycotting the test in protest against the NAEA policy implementation is a unique phenomenon. The other issue is the role of the media as a powerful tool for policy actors to achieve their aims in developing policies. The media has been described as useful soft capital, especially in network governance literature internationally, and the NAEA case involved the media in strengthening both bureaucratic strategies and network governance. However, the role of the media and students in developing policies has not been fully considered in this paper, and this can be explored by future research.

Declaration The author declares no potential conflicts of interest with respect to the research, authorship and publication of this article.

Funding The author received no financial support for the research, authorship or publication of this article.

\section{Notes}

1. Lim and Apple called these nations 'strong states' and suggested that 'strong states have historically assumed a larger presence in charting their society's moral compass....The state's enlarged role in all this in fact adds to the complicationsdrawing upon a wider set of ideological and moralizing discourses inevitably introduces into the field of pedagogic discourse a greater number of pedagogic agents' (2016: 11).

2. In international education policy literature, this was framed as 'from government to governance' (see Ball and Junemann, 2012; Bevir and Rhodes, 2003; Rizvi and Lingard, 2010), which indicates a notable shift from 'the government of a unitary state to governance in and by networks' (Bevir and Rhodes, 2003: 41). In this discourse, government in the old governance can be conceptualized as a political authority functioning within the bureaucratic administrative structures of the public sector, and this government has been replaced by polycentric networks of multiple actors in both public and private areas in the new governance (Rizvi and Lingard, 2010).

3. For example, 110 education researchers issued an official statement that the Ministry of Education's autonomous school policy establishes the notion of education with a narrow focus of competition and efficiency overlooking equity that had been a fundamental value in school systems and education reforms in Korea. 
4. Public school teachers and administrators are hired as national government officers and they transfer schools every 4-6 years within the regions. Since the government subsidizes salaries for private school teachers, most ordinary private schools do not have the right to select incoming students.

5. It is important to pay attention to Joo-ho Lee. He was a committee member of the May 31 Education Reform, a prior research fellow at a Korean economic institute, was appointed the Vice-Minister of Education in 2009, and served as the Minister of Education from 2010 to 2013, during the Lee administration. It is well known that while he was the Vice-Minister of Education he played key roles in relation to the Minister of Education at that time.

6. After continuous law suits, 13 teachers who were dismissed between 2008 and 2009 could return to their position in 2011.

7. After the inauguration of the new Korean government (President Moon Jae-in, progressive party), the planning committee of government administration announced the overall abolishment of the NAEA policy in July 2017. Since then, the NAEA has remained as a sampling test not requiring participation by all schools.

8. While Korea has a large private education market, 'market' principles in school education are limited compared to other countries. Most private institutions, so-called hagwon, offer supplementary learning opportunities for school subjects and other areas of students' development (e.g. art, physical education, music and other activities in addition to academic subjects). However, school education systems in Korea are not open to market principles. For example, school systems do not allow systems of school choice or charter school policies as in the United States. The school curriculum is based on national standards, and human resources for educators and administrators are controlled by central government, not based on a contract at the local or school level. Parents' individual choices are mostly reflected in the private education market in supporting their kids to be more competitive than others in their school education and offering more learning opportunities outside school.

9. Parents' resistance to the testing policy changes were observed in China (see Zhang, 2018), but public protest against the national policy is not often visible in Japan (Johnston, 2014). Even though these countries are considered as strong states, the historical and cultural context and political systems may be influential in shaping public responses to their education policy.

\section{References}

Allen K (2004) Max Weber: A Critical Introduction. London: Pluto Press.

Ball SJ (2012) Global Education Inc: New Policy Networks and the Neo-Liberal Imaginary. New York: Routledge.

Ball SJ and Junemann C (2012) Networks, New Governance and Education. Chicago: Policy Press.

Bevir M and Rhodes R (2003) Interpreting British Governance. London: Routledge.

Cho $\mathrm{H}$ (2008) Under the NAEA, sighs in the additional morning class of elementary schools. The Hankyoreh 21, 13 October. Available at: http://h21.hani.co.kr/arti/ special/special general/23530.html 
Choi D (2012) School incentives based on the results of NAEA in elementary schools. Eduhope, 30 May. Available at: http://news.eduhope.net/sub_read. html?uid=13934

Committee on Education Innovation (2006) Education reform report of each administration (III): The civilian government 94.5-97.6. Seoul: Presidential Committee on Education Innovation.

Convertino C, Brown A and Wilson MAF (2017) Public borders, private crossings: Anthropological approaches to neoliberalism in US educational policy and spaces. Policy Futures in Education 15(2): 126.

Du Gay P (1996) Consumption and Identity at Work. London: SAGE.

Gaches S (2018) Editorial: Preparing teachers to confront neoliberal discourses and to teach children equitably. Policy Futures in Education 16(6): 645-651. DOI: $10.1177 / 14782103187989952$.

Gopinathan S (2007) Globalisation, the Singapore developmental state and education policy: A thesis revisited. Globalisation, Societies and Education 5(1): 53-70.

Grek S and Ozga J (2010) Re-inventing public education: The new role of knowledge in education policy making. Public Policy and Administration 25(3): 271-288.

Grix J and Phillpots L (2011) Revisiting the 'governance narrative': 'Asymmetrical network governance' and the deviant case of the sports policy sector. Public Policy and Administration 26(1): 3-19.

Han S and Ye F (2017) China's education policy-making: A policy network perspective. Journal of Education Policy 32(4): 389-413.

Hartong S and Nikolai R (2017) Observing the 'local globalness' of policy transfer in education. Comparative Education Review 61(3): 519-537.

Harvey D (2005) A Brief History of Neoliberalism. Oxford: Oxford University Press.

Hwang C (2011) Diagnosis test for elementary and middle school students tomorrow, not taking the diagnosis test in Seoul from next year. Yeonhapnews, 7 March. Available at: http://www.yonhapnews.co.kr/bulletin/2011/03/07/02000 00000AKR20110307124351004.HTML

Jessop B (2002) The Future of the Capitalist State. Cambridge, UK: Polity Press. Johnston E (2014) Public protest in Japan: Power to the people? Japan Times, 20 December. Available at: https://www.japantimes.co.jp/life/2014/12/20/ general/public-protest-japan-power-people/\#.XPaUKC2ZM0o

Jung J (2015) The effectiveness of using results of the NAEA. Herald Economy, 1 December. Available at: http://news.heraldcorp.com/view. php?ud=20151201000396

KICE (2012) The improvement plan of educational policies based on international assessment results. Research report. Seoul, Korea: Korea Institute for Curriculum and Evaluation.

Kim H (2008) The directions and tasks of primary and secondary school autonomy policies. Paper presented at the 36th anniversary of the foundation of KEDI, Seoul, Korea, 28 August 2008. 
Kim SY (2008) The National Assessment of Educational Achievement: misunderstanding and truth. Korean Educational Administration Society Newsletter 98: 1-2.

Kim Y (2016) Tracing the discourse of autonomy around the education reform of the 1990s in Korea: A critical discourse. Journal of Educational Administration and Policy 1(1): 41-51.

Kim Y, Lim H, Lee K, et al. (2009) Developing systems for NAEA result utilization (RR 2009-28). Seoul: Korean Educational Development Institute.

Kim GH, Kim GS, Kim SS, et al. (2010) Country background report for Korea: International comparative research on evaluation system for school education. Korean Educational Development Institute.

Lawyers for a Democratic Society (2007) Written opinion about Enforcement Decree of the Act on Special Cases Concerning the Disclosure of Information by Education-Related Institutions. Available at: http://minbyun. org/?document srl $=13780$

Lee CJ and Kim Y (2016) Reflection on the education policy orientation in post-May 31 reform in Korea. Asia Pacific Education Review 17(3): 413-426.

Lee IF (2018) (Re)Landscaping early childhood education in East Asia: A neoliberal economic and political imaginary. Policy Futures in Education 16(1): 53-65.

Lee $S$ and Shouse RC (2011) The impact of prestige orientation on shadow education in south Korea. Sociology of Education 84(3): 212-224.

Lee Y (2009) Meaning of opening the NAEA results to the public and controversy. Yeonhapnews, 16 February. Available at: http://www.hangyo.com/news/article. html?no=27897

Lim L (2016) Globalization, the strong state and education policy: The politics of policy in Asia. Journal of Education Policy 31(6): 711-726.

Lim L and Apple MW (Eds) (2016) The Strong State and Curriculum Reform: Assessing the Politics and Possibilities of Educational Change in Asia. Abingdon: Routledge.

Lim SU (2011) Evaluating three years of Lee administration: School autonomous policy remains stationary. .. high school diversification has been failed. Kookminilbo, 25 February. Available at: http://news.kmib.co.kr/article/view. asp?arcid $=0004681963$

Lingard B, Martino W, Rezai-Rashti G et al. (2015) Globalizing educational accountabilities. New York: Routledge.

Lubienski C (2018) The critical challenge: Policy networks and market models for education. Policy Futures in Education 16(2): 156-168.

Maroy C, Pons X and Dupuy C (2017) Vernacular globalisations: Neo-statist accountability policies in France and Quebec education. Journal of Education Policy 32(1): 100-122.

Meyer H-D (2014) The OECD as pivot of the emerging global educational accountability regime: How accountable are the accountants? Teachers College Record 116: 1-20. 
Ministry of Education (2008) The plan of implementing the NAEA policy.

Press release. Available at: http://www.moe.go.kr/boardCnts/list.

do?boardID $=294 \& \mathrm{~m}=0503 \& \mathrm{~s}=$ moe

Ministry of Education (2013a) President work report: Happy education and creative human resource. Ministry of Education Report. Available at: http://www.korea. $\mathrm{kr} /$ archive/expDocView.do?docId=33657

Ministry of Education (2013b) Plan of the NAEA to support creative education. Ministry of Education Report. Seoul, Korea: Ministry of Education.

Nam K, Kim H and Shin H (2014) Restructuring methods for the National Assessment of Educational Achievement. Policy Research Project 2014-20. Ministry of Education. Available at: http://www.prism.go.kr/homepage/entire/ retrieveEntireDetail.do;jsessionid=CD3196DF5B514D71BB571D7F1F1BAE58. node02? cond_research name $=\&$ cond_research_start_date $=\&$ cond_research end_date $=\&$ research _id $=1342000-201500002 \&$ pageIndex $=21 \&$ leftMenuLe vel $=160$

Narodowski M, Gottau V and Moschetti M (2016) Quasi-State monopoly of the education system and socio-economic segregation in Argentina. Policy Futures in Education 14(6): 687-700.

Ong A (2007) Neoliberalism as a mobile technology. Transactions of the Institute of British Geographers 32(1): 3-8.

Park N (2013) Analysis on the background and the context of adopting educational accountability system to elementary and secondary education. Korean Journal of Educational Administration 31(2): 347-376.

Park Y (2012) Offices of Education evaluation result: Gwang-ju, Seoul, Kang-won, and Kyung-gi at the bottom. Yeonhapnews, 9 July. Available at: http://www.yonhapnews.co.kr/bulletin/2012/07/09/0200000000 AKR20120709073500004.HTML

Peters BG (2000) Governance and comparative politics. In: Pierre J (ed) Debating Governance: Authority, Steering, and Democracy. New York: Oxford University Press, pp. 36-53.

Peters MA (2012) Neoliberalism, Education and the Crisis of Western Capitalism. Policy Futures in Education 10(2): 134-141. DOI: 10.2304/pfie.2012.10.2.1343.

Pierre J (ed) (2000) Debating Governance: Authority, Steering, and Democracy. New York: Oxford University Press.

Rhodes RA (1997) Understanding Governance: Policy Networks, Governance, Lawyers for a Democratic Society Reflexivity and Accountability. Buckingham: Open University Press.

Rhodes RA (2007) Understanding governance: Ten years on. Organization Studies 28(8): 1243-1264.

Rizvi F and Lingard B (2010) Globalizing Education Policy. New York: Routledge.

Robertson SL (2012) Placing teachers in global governance agendas. Comparative Education Review 56(4): 584-607.

Rönnberg L (2017) From national policy-making to global edu-business: Swedish edu-preneurs on the move. Journal of Education Policy 32(2): 234-249. 
Shahjahan RA (2012) The roles of international organizations (IOs) in globalizing higher education policy. In: Smart JC and Paulsen MB (eds) Higher Education:

Handbook of Theory and Research. New York: Oxford University Press, pp. 69-407.

Shaw S, Elston J and Abbott S (2004) Comparative analysis of health policy implementation. Policy Studies 25(4): 259-266.

Shin H and Joo Y (2013) Global governance and educational policy in Korea: Focusing on OECD/ PISA. Korean Journal of Educational Research 51(3): 133-159.

Shore C and Wright S (2000) Conceptulising policy: Technologies of governance and the politics of visibility. In: Shore C, Wright S and Però D (eds) Policy Worlds: Anthropology and the Analysis of Contemporary Power. New York, NY: Berghahn Books, pp. 1-25.

Statistics Korea (2017) Private education expenses for elementary and secondary school students in 2016. Press release.

Steiner-Khamsi G (2012) The global/local nexus in comparative policy studies: Analysing the triple bonus system in Mongolia over time. Comparative Education 48(4): 455-471.

Suh J (2009) Future tasks of Myung-bak Lee's government education reform implementation. Journal of Educational Administration 27(2): 481-499.

Sung YK (2011) Cultivating borrowed futures: The politics of neoliberal loanwords in South Korean cross-national policy borrowing. Comparative Education 47(4): 523-538.

Sung YK and Kim-Koh JH (2009) Without knowing the context, copying the American NCLB for the NAEA. Secondary Education 229(3): 113-119.

Takayama K (2008) The politics of international league tables: PISA in Japan's achievement crisis debate. Comparative Education 44(4): 387-407.

Tesar M (2019) Global politics and local impacts on educational policy. Policy Futures in Education 17(3): 302-305.

Tuck E (2013) Neoliberalism as nihilism? A commentary on educational accountability, teacher education, and school reform. Journal for Critical Education Policy Studies 11(2): 324-347.

Uhm J and Park Y (2008) Middle school students in North Julla Province rejected the NAEA. Kyunghang Shinmun, 23 December. Available at: http://m.khan.co.kr/view.

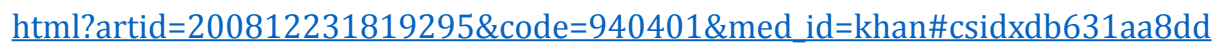
271dc95bc83f0b4ec6b52

Verger A, Altinyelken H and De Koning M (2013) Global managerial education reforms and teachers. Education International Research Institute IS Academic Program. Available at: http://download.ei-ie.org/Docs/WebDepot/Global\%20 Managerial\%20Education\%20Reforms\%20and\%20Teachers.pdf

Weber M (1958) Essays in Sociology. Gerth H and Mills C (trans). New York: Oxford University Press.

Weber M (1968) Economy and Society. Roth G and Wittich C (trans). New York: Bedminster Press.

Wood E (1997) Modernity, postmodernity or capitalism? Review of International Political Economy 4(3): 539-560. 
Yeonhapnews (2008) Increasing debates on the NAEA. 30 September. Available at: http://www.hangyo.com/news/article.html?no=26443

Yun S (2009) Protesting NAEA, students go field trips in October 13th and 14th. Ohmynews, 30 September. Available at: http://www.ohmynews.com/NWS Web/ View/at pg.aspx?CNTN CD=A0001227274

Zhang H (2018) Parents protest plan to assign children to boarding schools to reduce classroom sizes. Global Times, 4 September. Available at: http://www. globaltimes.cn/content/1118258.shtml 